\title{
Murine Retrovirus Containing Human PDGFB CDNA
}

National Cancer Institute

\section{Source}

National Cancer Institute. Murine Retrovirus Containing Human PDGFB CDNA. NCI

Thesaurus. Code C29907.

A murine retrovirus that contains plasmid DNA (CDNA) coding for the B chain of plateletderived growth factor (PDGFB). Overexpressed in some human brain tumors, PDGFB and PDGF receptors may stimulate tumor development in an autocrine manner. A murine retrovirus containing human PDGFB CDNA may be used to induce brain tumors in animal models of brain tumorigenesis. ( $\mathrm{NCl} 04)$ 